\title{
GIORDANO FROSINI, PER UN MONDO NUOVO. LA CHIESA INIZIO E SERVA DEL REGNO, BOLOGNA 2010, SS. 192
}

O potrzebie nieustannego pogłębiania nauki Soboru Watykańskiego II mówi jeden z bardziej reprezentatywnych przedstawicieli teologii włoskiej - Giordano Frosini (ur. 1927). Ukazaną przez Vaticanum II w nowym świetle problematykę Kościoła podjął on już w swej publikacji pt. Una Chiesa possibile (Bologna 1995). W samym centrum zainteresowania jednej z ostatnich jego publikacji jest relacja Kościoła do Królestwa Bożego. Emerytowany wykładowca teologii na Wydziale Teologicznym Centralnych Włoch i Autor wielu publikacji z zakresu eklezjologii i eschatologii, mons. Giordano Frosini nie ma najmniejszej wątpliwości, że dla właściwego zrozumienia tajemnicy Kościoła nieodzowne jest odniesienie jego rzeczywistości do prawdy o Królestwie Bożym. Zanim jednak Frosini podejmie się ukazania, w czym wyraża się bycie przez Kościół początkiem i sługą Królestwa, najpierw ukazuje w oparciu o najbardziej autorytatywne źródło, jakim jest Biblia, czym jest samo Królestwo. Autor stosuje tu właściwą sobie metodę kręgu hermeneutycznego [por. La Chiesa siete voi. Per una teologia conciliare del popolo di Dio, Fossano 2009], która odznacza się tym, że wychodzi on od analizy sytuacji aktualnej, a następnie przechodzi do tradycji źródłowej, tradycji interpretacji, po czym z powrotem powraca do sytuacji obecnej, niejako do punktu wyjścia, który tym razem zostaje ubogacony całym dotychczasowym doświadczeniem i na nowo odczytany. Nadejście Królestwa znajduje się w samym centrum przepowiadania Pana Jezusa. Przepowiadanie to jednak, jak dostrzega Frosini, zostało przynajmniej po części przysłonięte przez kerygmat paschalny. Doświadczenie śmierci i zmartwychwstania Chrystusa było tak silne, że zdominowało ono zawartość pism apostolskich. Właściwe ukazanie prawdy, że Jezus jest zasadniczo Prorokiem Królestwa Bożego znajduje swoje bezpośrednie odniesienie w prawdzie o Kościele.

Bycie przez Kościół początkiem Królestwa oznacza urzeczywistnianie, nawet jeśli nie w sposób pełny, jego cech charakterystycznych, takich jak: prawda i życie, świętość i łaska, sprawiedliwość, miłość i pokój. Tak jak światło w ciemności, tak Kościół w świecie jest dla ludzi znakiem i narzędziem nowego życia w Chrystusie, życia opartego na wskazaniach Ewangelii i ożywianego duchem błogosławieństw. Kościół nie utożsamia się z jakimkolwiek ugrupowaniem ludzkim, ani też nie jest dla społeczności ludzkich wspólnotą alternatywną. Kościół został powołany, aby być „terenem szczególnie urodzajnym” dla Królestwa. Niejako pierwszą formą służby Kościoła na rzecz Królestwa jest właśnie to nowe życie, jakie rozwija się we wspólnocie Kościoła. W tym względzie Kościół musi nieustannie wzorować się na 
samym Chrystusie, który jako pierwszy służył Królestwu. Frosini, odnosząc się do całego bogactwa odnowionej liturgii (np. Modlitwa eucharystyczna Vc), podkreśla, jak bardzo pomaga ona wspólnocie Kościoła służyć Królestwu i urzeczywistniać je. Kościół poprzez właściwą mu „rezerwę eschatologiczną” pozostaje krytycznym sumieniem społeczeństwa. Natomiast dzięki znamiennej obecności Ducha Świętego Kościół powinien być też uprzywilejowaną ojczyzną wolności, która jest istotną cechą Królestwa. Wolność i wyzwolenie, wpisane w samo serce przekazu ewangelijnego, nie mogą być interpretowane na szkodę dla samej Ewangelii, tak jak ma to miejsce w przypadku teologii wyzwolenia. W świecie pełnym nierówności i niesprawiedliwości Kościół ma służyć prawdzie, a tym samym piętnować niesprawiedliwość.

Aby służba Kościoła na rzecz Królestwa zachowała właściwe sobie granice, Kościół musi zwracać nieustanną uwagę na dwa grożące mu niebezpieczeństwa: skoncentrowania się na teraźniejszości ze szkodą dla przyszłości, a także na przyszłości ze szkodą dla teraźniejszości. Jest to w swej istocie pokusa tak zwanego „już”, a także pokusa tak zwanego ,jeszcze nie”. Kościól, a wraz z nim każdy poszczególny człowiek, powinien włączyć swój niezastąpiony wkład w nadejście Królestwa eschatologicznego. Zanim jednak to ostateczne Królestwo nadejdzie, tu na ziemi pozostaje ono pod znakiem krzyża, a co za tym idzie także prześladowania i cierpienia. Najtrudniejszym jednak doświadczeniom chrześcijanina towarzyszy nadzieja, i to ona jest jednym z największych jego sekretów.

ks. Sylwester Jaśkiewicz 
